\title{
THE MODES OF TELIOSPORE GERMINATION \\ OF USTILAGO TRICHOPHORA (LINK) KUNZE EX KÖRNICKE OCCURRING IN POLAND
}

\author{
WOJCIECH PUSZ \\ Departament of Plant Protection \\ Division of Phytopathology, Agricultural University \\ Cybulskiego 32, 50-205 Wrocław, Poland \\ e-mail: agrostrona@poczta.fm
}

(Received: Jannuary 29, 2003. Accepted: June 23, 2003)

\begin{abstract}
Ustilago trichophora affects Echinochloa crus-galli and other species of Echinochloa genus. U. trichophora is a member of the order Ustilaginales, of which the germinating teliospores form a promycelium with sporidia. Investigations by Ingold (1996) proved that spores coming from various parts of the world germinate in a different way. The aim of the investigation was to determine the mode of germination of $U$. trichophora spores found in Poland.
\end{abstract}

KEY WORDS: Echinochloe crus-galli, Ustilaginales.

\section{INTRODUCTION}

Ustilago trichophora is a pathogenic fungus infecting grass species of the genus Echinochloa. In the literature there are only few publications concerning this pathogen. In September 1998 Ustilago trichophora was found in association with cockspur panic-grass [Echinochloa crusgalli (L.) Beauv.] growing near Wrocław (Pusz, Kita 2001). In the next years $U$. trichophora has also been found in Rakowice Wielkie located in Lower Silesia (Madej, Błaszkowski, Tadych 2001). U. trichophora has probably got into the Polish territory from Germany or the Czech Republic, where it had been previously recorded (Mordue 1995; Ingold 1996).

U. trichophora is a member of the order Ustilaginales, of which the germinating teliospores form a promycelium with sporidia. The investigations by Ingold (1996) proved that spores coming from various parts of the world germinate in a different way.

The aim of the investigation was to determine the mode of germination of $U$. trichophora spores found in Poland.

\section{MATERIAL AND METHODS}

Clusters of teliospores associated with cockspur panicgrass growing in a corn field were collected in October 2001. In the laboratory, teliospores were spread on the surface of Petri dishes containing 2\% malt agar. They were subsequently incubated at room temperature (about $20^{\circ} \mathrm{C}$ ).
Beginning from about the $18^{\text {th }}$ hour of incubation the spore germination was daily observed, as Ingold (1996) suggested. One- $\mathrm{cm}^{2}$ fragments of the nutrient medium with abundantly germinating teliospores were cut out and prepared for microscopic observation (Ingold 1996). The germinating spores were examined and measured at one-hour intervals through four hours.

\section{RESULTS}

The germination of teliospores of $U$. trichophora examined in this study started after 20-24 hours of their incubation on $2 \%$ malt agar. To determine the mode of germination of $U$. trichophora teliospores coming from Poland, two spores differing in diameter were selected from the numerous incubated material.

The first spore of $9.6 \mu \mathrm{m}$ in diameter started to germinate at the $20^{\text {th }}$ hour of incubation producing a promycelium of a length of $24 \mu \mathrm{m}$ (Fig. 1Aa). In the next hour, a second offshoot, of $16.8 \mu \mathrm{m}$ in length, appeared (Fig. 1Ab). The first offshoot ceased to grow. At the third hour of incubation, a third offshoot of a length of $19.2 \mu \mathrm{m}$ of the promycelium developed (Fig. 1Ac). Sporidia started to form at the end of each of the offshoots so far produced. At the forth hour of incubation, a forth offshoot of the promycelium formed. At that time, the sporidia were present on all the developed offshoots (Fig. 1Ad).

The second observed teliospore was bigger, having a diameter $12 \mu \mathrm{m}$. Twenty hours after sowing, a promyce- 
A

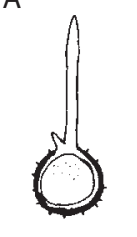

a

B

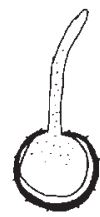

a

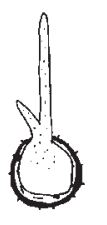

b

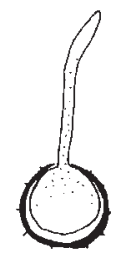

b

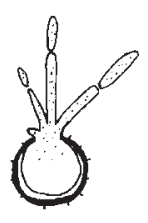

$\mathrm{C}$

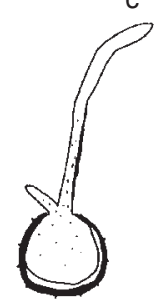

C
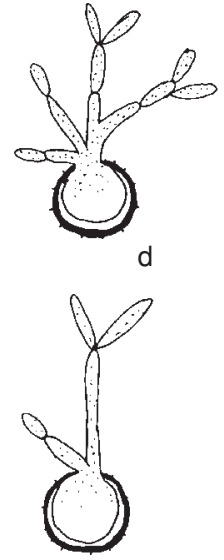

d
Fig. 1. The modes (A, B) and stages (a-d) of germination of Ustilago trichophora teliospores determined at 1-hour intervals. Draw by Z. Nowak.

lium of a length of $28.8 \mu \mathrm{m}$ developed from the spore (Fig. $1 \mathrm{Ba})$. One hour later, the length of the promycelium increased up to $38.4 \mu \mathrm{m}$ and an offshoot of a length of 16.8 $\mu \mathrm{m}$ developed in the next hour (Fig. 1Bb, Fig. 1Bc). At the end of the first offshoot, a sporidium was noticed. At the last observation, sporidia were present on all the offshoots produced (Fig. 1Bd).

Most of the remaining spores germinated similarly as those characterised above. The attempt to germinate spores on a potato nutrient agar medium failed. None of the spores formed a promycelium.

\section{DISCUSSION}

The comparison of the mode of germination of the teliospores of $U$. trichophora found in Poland with that of spores coming from Germany, Hungary, India and Venezuela characterised by Ingold (1996) showed that one of the Polish teliospores investigated germinated identically as those from Germany and Venezuela. The germinating spore first produced a non-branched hypha of a promycelium, from which later four offshoots grew up. Sporidia were produced at the end of each of the offshoots of the promycelium formed (Fig. 1A). Both the length of the promycelia of the compared specimens of different origin and their rate of growth were also similar.

The second Polish U. trichophora (Fig. 1B) selected teliospore germinated LIKE spores coming from India. The promycelium of the germinated spore consisted of the Polish and Hungarian teliospores. According to Ingold (1996), germinating spores from Hungary, produce a short $(2 \mu \mathrm{m})$ promycelium with no branches.

The percent of germination determined by the author of this papers was higher when the teliospores occurred in aggregates. A similar phenomenon was observed by Madej, Błaszkowski and Tadych (2001).

The similar mode of germination of $U$. trichophora teliospores coming from Poland and those from Germany and Venezuela suggest that $U$. trichophora has been introduced to Poland from Germany. This should be supported in further investigations. According to Ingold (1996), the mode of germination of teliospores of fungi of the order Ustilaginales may not depend on their geographical origin.

\section{LITERATURE CITED}

INGOLD C.T. 1996. Different patterns of teliospore germination in Ustilago trichophora. Mycological Res. 100 (4): 418-420.

MADEJ T., BŁASZKOWSKI J., TADYCH M. 2001. Ustilago trichophora (H.F. Link) F. Körnicke, a fungus newly found in Poland. Acta Soc. Bot. Pol. 70, 1: 43-46.

MORDUE J. 1995. IMI descriptions of fungi and bacteria. Mycopathologia 131: 59-61.

PUSZ W., KITA W. 2001. The occurrence of Ustilago trichophora (Link) Kunze ex Körnicke in Poland. Phytopath. Pol. 22: 183-186.

\title{
TYPY KIEŁKOWANIA TELIOSPOR USTILAGO TRICHOPHORA (LINK) KUNZE EX KÖRNICKE WYSTĘPUJĄCEGO W POLSCE
}

\section{STRESZCZENIE}

\begin{abstract}
Zbadano sposób kiełkowania zarodników Ustilago trichophora wystepującego w Polsce. Zarodniki U. trichophora wysiano na szalki Petriego z $2 \%$ pożywką maltozową. Teliospory kiełkowały od 18 do 24 godzin od momentu wysiania na pożywke. Obserwacje kiełkowania prowadzone były co godzinę. Stwierdzono, że większość teliospor kiełkuje w krótką przedgrzybnię, z której wyodrębniają się sporydia. Część teliospor skiełkowała w długą przedgrzybnię na której wytworzyły się sporydia.

Porównano sposób kiełkowania polskiej populacji U. trichophora z populacjami pochodzącymi z Indii, Niemiec, Węgier i Wenezueli, a opisanymi w pracy Ingolda (1996). Stwierdzono, że teliospory U. trichophora zebrane w Polsce kiełkują w podobny sposób co zarodniki z Niemiec i Wenezueli, a odmienny niż teliospory pochodzące z Węgier i Indii.
\end{abstract}

